\title{
Different actions of endothelin-1 on chemokine production in rat cultured astrocytes: reduction of CX3CL1/fractalkine and an increase in CCL2/ MCP-1 and CXCL1/CINC-1
}

\author{
Yutaka Koyama*, Mao Kotani, Tadateru Sawamura, Miho Kuribayashi, Rika Konishi and Shotaro Michinaga
}

\begin{abstract}
Background: Chemokines are involved in many pathological responses of the brain. Astrocytes produce various chemokines in brain disorders, but little is known about the factors that regulate astrocytic chemokine production. Endothelins (ETs) have been shown to regulate astrocytic functions through $\mathrm{ET}_{\mathrm{B}}$ receptors. In this study, the effects of ETs on chemokine production were examined in rat cerebral cultured astrocytes.

Methods: Astrocytes were prepared from the cerebra of one- to two-day-old Wistar rats and cultured in serumcontaining medium. After serum-starvation for 48 hours, astrocytes were treated with ETs. Total RNA was extracted using an acid-phenol method and expression of chemokine mRNAs was determined by quantitative RT-PCR. The release of chemokines was measured by ELISA.

Results: Treatment of cultured astrocytes with ET-1 and Ala ${ }^{1,3,11,15}-\mathrm{ET}-1$, an $\mathrm{ET}_{\mathrm{B}}$ agonist, increased mRNA levels of CCL2/MCP1 and CXCL1/CINC-1. In contrast, CX3CL1/fractalkine mRNA expression decreased in the presence of ET-1 and Ala ${ }^{1,3,11,15}$-ET-1. The effect of ET-1 on chemokine mRNA expression was inhibited by BQ788, an $\mathrm{ET}_{\mathrm{B}}$ antagonist. ET-1 increased CCL2 and CXCL1 release from cultured astrocytes, but decreased that of CX3CL1. The increase in CCL2 and CXCL1 expression by ET-1 was inhibited by actinomycin D, pyrrolidine dithiocarbamate, SN50, mithramycin, SB203580 and SP600125. The decrease in CX3CL1 expression by ET-1 was inhibited by cycloheximide, $\mathrm{Ca}^{2+}$ chelation and staurosporine.

Conclusion: These findings suggest that ETs are one of the factors regulating astrocytic chemokine production. Astrocyte-derived chemokines are involved in pathophysiological responses of neurons and microglia. Therefore, the ET-induced alterations of astrocytic chemokine production are of pathophysiological significance in damaged brains.
\end{abstract}

Keywords: Endothelin-1, Brain injury, Chemokines, Gene expression

\section{Background}

Chemokines were originally identified as a family of small proteins having chemoattractive activities on inflammatory cells. Various chemokines are constitutively or inducibly expressed in the brain and are involved in physiological or pathological nerve functions [1,2]. In brain ischemia, head trauma and neurodegenerative diseases, the expression of brain chemokines is altered, which modulates neu-

\footnotetext{
* Correspondence: koyamay@osaka-ohtani.ac.jp

Laboratory of Pharmacology, Faculty of Pharmacy, Osaka Ohtani University, 3-11-1 Nishikiori-Kita, Tonda-bayashi, Osaka 584-8540, Japan
}

roinflammation and the repair process of damaged nerve tissues [3]. Astrocytes are one of the chemokine-producing cells in the brain. Immunohistochemical observations on damaged nerve tissues showed that production of brain chemokines, including CCL2/monocyte chemoattractant protein-1 (MCP-1) and CXCL1/cytokine-induced neutrophil chemoattractant-1 (CINC-1), increased in astrocytes [4-6]. Astrocyte-derived chemokines act on brain microvascular endothelial cells. The chemokine-induced functional changes of vascular endothelial cells promote infiltration of inflammatory cells and neovascularization at 
the damaged areas. In addition to vascular endothelial cells, expression of chemokine receptors in normal and pathological brains were shown in neurons, astrocytes and microglia [1], suggesting that the function of these brain cells is also regulated by chemokines. During brain injury, the production of astrocyte-derived extracellular signal molecules affects the viability of damaged neurons and the repair of nerve tissues [7]. Studies in cultured neurons showed that some types of chemokines had a protective effect against neuronal damage, while other types were detrimental [8-12]. In brain disorders, microglia become activated. Astrocytes are also involved in the regulation of microglial activation by releasing signal molecules [7]. Microglial activation is accompanied by the enhancement of microglial function, including phagocytosis, migration and pro-inflammatory cytokine production. In vitro and in vivo studies showed that these microglial functions are modulated by certain chemokines [13-19]. From the various actions of brain chemokines, important roles of astrocytic chemokine production in neuroinflammation and the tissue repair process after brain injury are proposed. However, the regulatory mechanisms of chemokine production in astrocytes are not fully understood.

Endothelins (ETs), a vasoconstrictor peptide family, are present in the brain. The production of brain ETs is increased in various brain disorders. Increases in brain ETs are involved in the pathophysiological responses of nerve tissues [20-22]. Receptors for ETs are classified as $\mathrm{ET}_{\mathrm{A}}$ or $\mathrm{ET}_{\mathrm{B}}$ types. In the brain, high expression of $\mathrm{ET}_{\mathrm{B}}$ receptors was observed in astrocytes [23,24]. ETs have been shown to regulate the function of astrocytes through $\mathrm{ET}_{\mathrm{B}}$ receptors. In animal brain injury models, $\mathrm{ET}_{\mathrm{B}}$ antagonists reduced astrocytic proliferation [25,26], indicating that $\mathrm{ET}_{\mathrm{B}}$ receptors are involved in the induction of astrogliosis. Activation of $\mathrm{ET}_{\mathrm{B}}$ receptors was shown to induce the production of several signaling molecules, such as neurotrophic factors and cytokines, in cultured astrocytes and in the rat brain [27]. These findings suggest that ETs regulate the pathophysiological response of the damaged brain by modulating the production of astrocytic signaling molecules. As for the production of chemokines in the brain, we previously showed that administration of an $\mathrm{ET}_{\mathrm{B}}$ agonist increased CCL2 and CXCL1 production in the adult rat brain [28]. In this study, to clarify the role of $\mathrm{ET}_{\mathrm{B}}$ receptors in astrocytic chemokine production, the effect of ETs on chemokine expression in rat cultured astrocytes was examined.

\section{Methods}

\section{Preparation of rat primary cultured astrocytes}

All experimental protocols conformed to the Guiding Principles for the Care and Use of Animals of the Japanese Pharmacological Society and were approved by the Animal Experiment Committee of Osaka Ohtani University.
Astrocytes were prepared from the cerebra of one- to twoday-old Wistar rats as described previously [29]. The isolated cells were seeded at $1 \times 10^{4}$ cells $/ \mathrm{cm}^{2}$ in $75-\mathrm{cm}^{2}$ culture flasks and grown in minimal essential medium (MEM) supplemented with $10 \%$ fetal calf serum. To remove small process-bearing cells (mainly oligodendrocyte progenitors and microglia from the protoplasmic cell layer), the culture flasks were shaken at $250 \mathrm{rpm}$ overnight, 10 to 14 days after seeding. The monolayer cells were trypsinized and seeded on six-well culture plates. Astrocytes were identified by immunocytochemical observations of glial fibrillary acidic protein (GFAP), an astrocytic marker protein. At this stage, approximately $95 \%$ of cells showed immunoreactivity for GFAP. Cultured neurons and microglia were prepared from the rat cerebrum according to previously described methods [29].

\section{Treatment with ETs and the other drugs}

Before treatment with ETs and other drugs, astrocytes in six-well culture plates were cultured in serum-free MEM for 48 hours. ET-1 and Ala ${ }^{1,3,11,15}$-ET-1 were dissolved in distilled $\mathrm{H}_{2} \mathrm{O}$ to make stock solutions. ET antagonists and signal transduction inhibitors were dissolved in dimethyl sulfoxide (DMSO). Treatments of cultured astrocytes with ETs and other drugs were started by addition of the stock solutions to serum-free MEM. As a control for treatments with ET antagonists and signal transduction inhibitors, equal volumes of DMSO were included in the medium.

Table 1 Comparison of chemokine mRNA copy numbers in neurons, astrocytes and microglia derived from the rat cerebrum

\begin{tabular}{lccc}
\hline \multicolumn{4}{c}{ mRNA copy number } \\
\hline \multicolumn{4}{c}{$(\times \mathbf{1 0} \mathbf{3} / \boldsymbol{\mu g}$ total RNA $)$} \\
& Neuron & Astrocyte & Microglia \\
CCL2/MCP-1 & $189.9 \pm 9.8$ & $3050.8 \pm 521.5$ & $148.9 \pm 31.6$ \\
CCL5/RANTES & $10.3 \pm 0.7$ & $52.5 \pm 18.7$ & $4.3 \pm 2.2$ \\
CXCL1/CINC-1 & $22.0 \pm 2.2$ & $1410.0 \pm 266.9$ & $34.4 \pm 18.1$ \\
CXCL12/SDF-1a & $92.1 \pm 4.0$ & $255.4 \pm 45.7$ & $29.1 \pm 13.6$ \\
CX3CL1/ & $1,118.1 \pm 108.4$ & $1,721.0 \pm 303.5$ & $23.4 \pm 6.6$ \\
fractalkine & & & \\
G3PDH & $40,081.9 \pm$ & $46,575.5 \pm$ & $48,586.5 \pm$ \\
& $7,335.2$ & $6,274.4$ & $5,733.6$ \\
\hline
\end{tabular}

Cultured neurons, astrocytes and microglia were prepared from the cerebra of Wistar rats and total RNA was extracted. The copy numbers of chemokine mRNA were determined by quantitative RT-PCR. The copy numbers of G3PDH mRNA in the same samples were also determined as an internal standard. Data are the mean \pm SEM of 6 to 10 different preparations presented as $\times 10^{3}$ copy numbers/ $\mu$ g total RNA. G3PDH, glyceraldehyde-3-phosphate dehydrogenase; SEM, standard error of the mean. 
(A)
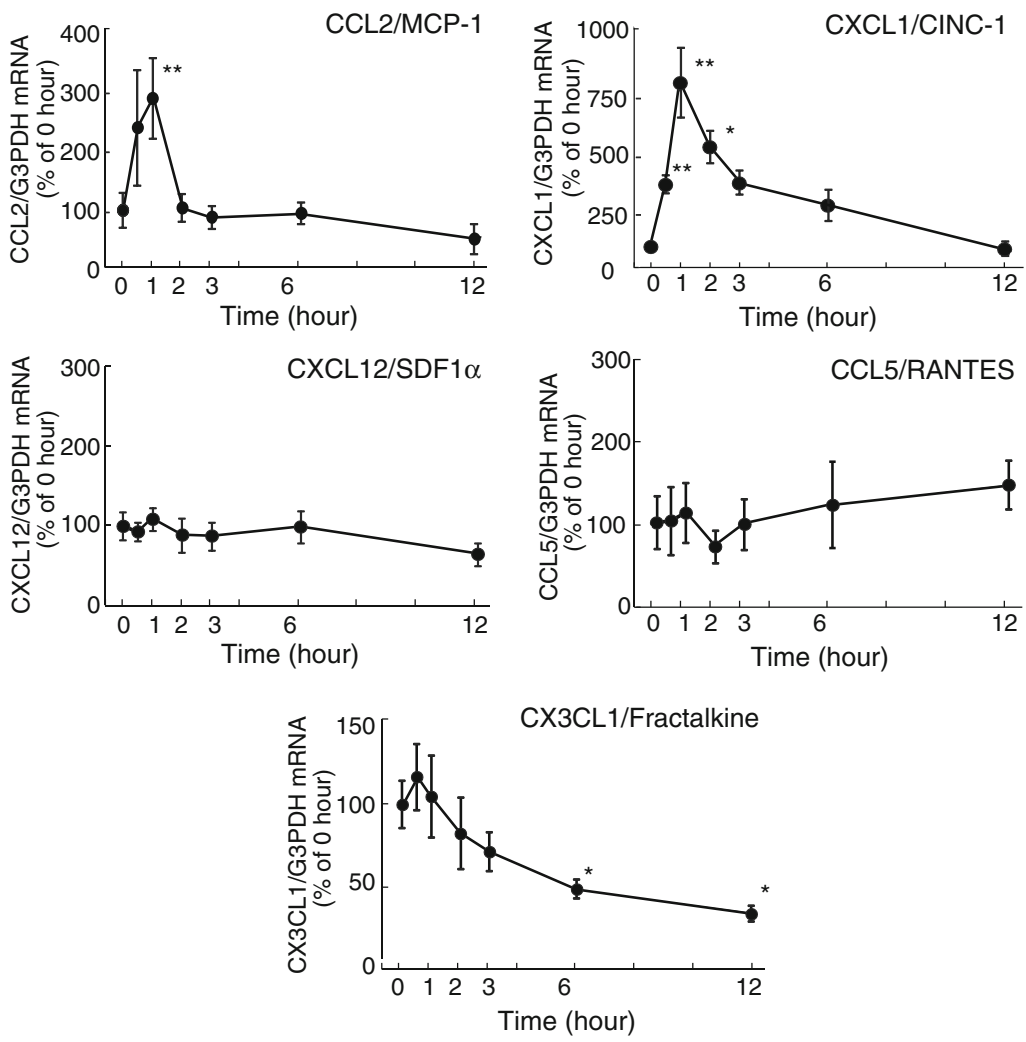

(B)
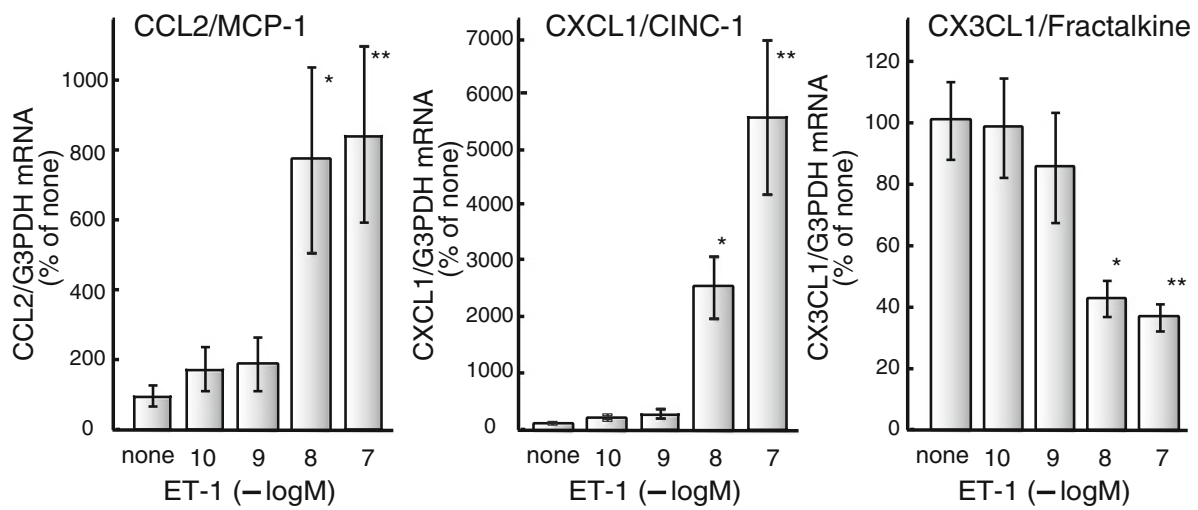

Figure 1 Effect of ET-1 on chemokine mRNA expression in cultured rat astrocytes. (A) Serum-starved astrocytes were treated with $100 \mathrm{nM}$ ET-1 for the times indicated. The expression of CCL2, CXCL1, CCL5, CXCL12 and CX3CL1 mRNA was normalized to G3PDH and expressed as the $\%$ of 0 hour. Data are the mean \pm SEM of 6 to 16 experiments. ${ }^{*} P<0.05$ and ${ }^{* *} P<0.01$ versus 0 hour by one-way ANOVA followed by Dunnett's test. (B) Astrocytes were treated with the indicated concentrations of ET-1 for one (CCL2 and CXCL1) or six (CX3CL1) hours. Data are the mean \pm SEM of five to eight experiments. ${ }^{*} P<0.05$ and ${ }^{*} P<0.01$ versus none by one-way ANOVA followed by Dunnett's test. ANOVA, analysis of variance; ET-1, endothelin-1; G3PDH, glyceraldehyde-3-phosphate dehydrogenase; SEM, standard error of the mean.

\section{Measurement of chemokine mRNA levels by quantitative RT-PCR}

Total RNA was extracted using an acid-phenol method as described previously [29]. First-strand cDNA was synthesized from total RNA $(1 \mu \mathrm{g})$ using MMLV reverse transcriptase (200 U; Invitrogen, Carlsbad, CA, USA), random hexanucleotides (0.2 $\mu \mathrm{g}$; Invitrogen) and an RNase inhibitor (20 U; Takara, Tokyo, Japan) in $10 \mu \mathrm{L}$ of buffer supplied by the enzyme manufacturer. The mRNA levels of chemokines in each sample were determined by quantitative PCR using SYBR Green fluorescent probes. Each reverse transcription product was added to the SYBR Green Master Mix (Toyobo, Tokyo, Japan) along with the primer pairs, and the mixture was placed in a thermal cycler (Opticom 2; MJ Research, Waltham, MA, USA). The following primer pairs were used: 
CCL2,

5' -TTCACTGGCAAGATGATCCC-3' and 5' -

TGCTTGAGGTGGTTGTGGAA-3';

CXCL1,

5' - GAAGATAGATTGCACCGATG -3' and 5' -

CATAGCCTCTCACACATTTC-3';

CCL5/RANTES,

5' -CACCGTCATCCTCGTTGC-3' and 5' -

CACTTGGCGGTTCCTTCG-3';

CX3CL1/fractalkine,

5' - GAATTCCTGGCGGGTCAGCACCTCGGCATA-

$3^{\prime}$ and $5^{\prime}$ -

AAGCTTTTACAGGGCAGCCGTCTGGTGGT-3'

CXCL12/ stromal cell-derived factor-1 (SDF-1),

5' -TTGCCAGCACAAAGACACTCC-3' and 5' CTCCAAAGCAAACCGAATACAG-3';

glyceraldehydes-3-phosphate dehydrogenase (G3PDH), 5'-CTCATGACCACAGTCCATGC-3' and 5' -

TACATTGGGGGTAGGAACAC-3'.

As a standard for the copy number of PCR products, serial dilutions of each amplicon were amplified in the same manner. The amount of cDNA was calculated as the copy number of each reverse-transcription product equivalent to $1 \mu \mathrm{g}$ of total RNA and normalized to the value for $\mathrm{G} 3 \mathrm{PDH}$.

\section{Determination of chemokine proteins}

Serum-starved astrocytes in six-well plates were treated with ET-1 and the culture medium collected. The level of immunoreactive chemokines in the culture media were determined using an ELISA kit for rat CCL2 (Biosource, Camarillo, CA, USA), CXCL1 (Immuno-Biological Laboratories, Gunma, Japan,) and CX3CL1 (RayBiotech, Norcross, GA, USA) according to the manufacturers' protocols. The protein content in each well was determined with a BCA protein assay kit (Pierce, Rockford, IL, USA).

\section{Results}

\section{Effect of ETs on chemokine production in cultured} astrocytes

In the adult rat brain, the mRNA of CCL2, CXCL1, CCL5/RANTES, CX3CL1/fractalkine and CXCL12/SDF1 has been previously detected [4,6,30-32]. These chemokines are produced by different brain cells, including neurons, microglia and astrocytes [3]. Thus, at first, copy numbers of these chemokine mRNAs in cultured neurons, microglia and astrocytes were determined. Copy numbers of CCL2 and CXCL1 in non-stimulated cultured astrocytes were 10 to 50 times higher than those in neurons and microglia (Table 1). Expression of CX3CL1 was high in neurons and astrocytes. Copy numbers of CXCL12 and RANTES were of similar level among these cells.

Treatment of cultured astrocytes with 100 nM ET-1 increased mRNA levels of CCL2 and CXCL1, where the maximum increase was observed in one hour (Figure 1A). In contrast, CX3CL1 mRNA decreased following ET-1 exposure to approximately $40 \%$ of levels observed in non-treated cells in six hours. ET-1 did not affect mRNA levels of CCL5 and CXCL12. The effect of ET-1 on CCL2 and CXCL1 mRNA levels was dose-dependent and a significant increase was observed at $10 \mathrm{nM}$ (Figure 1B). The ET-induced decrease in astrocytic CX3CL1 mRNA was significant at $10 \mathrm{nM}$. Treatment with $100 \mathrm{nM}$ Ala ${ }^{1,3,11,15}$-ET-1, a selective $\mathrm{ET}_{\mathrm{B}}$ agonist, also increased CCL2 and CXCL1 mRNA levels in cultured astrocytes, while it decreased CX3CL1 mRNA (Figure 2). Increases in CCL2 and CXCL1 mRNA by ET-1 were inhibited by $1 \mu \mathrm{M}$ BQ788, an $\mathrm{ET}_{\mathrm{B}}$ antagonist (Figure 3). BQ788 also inhibited the ET-induced decrease in CX3CL1 mRNA.

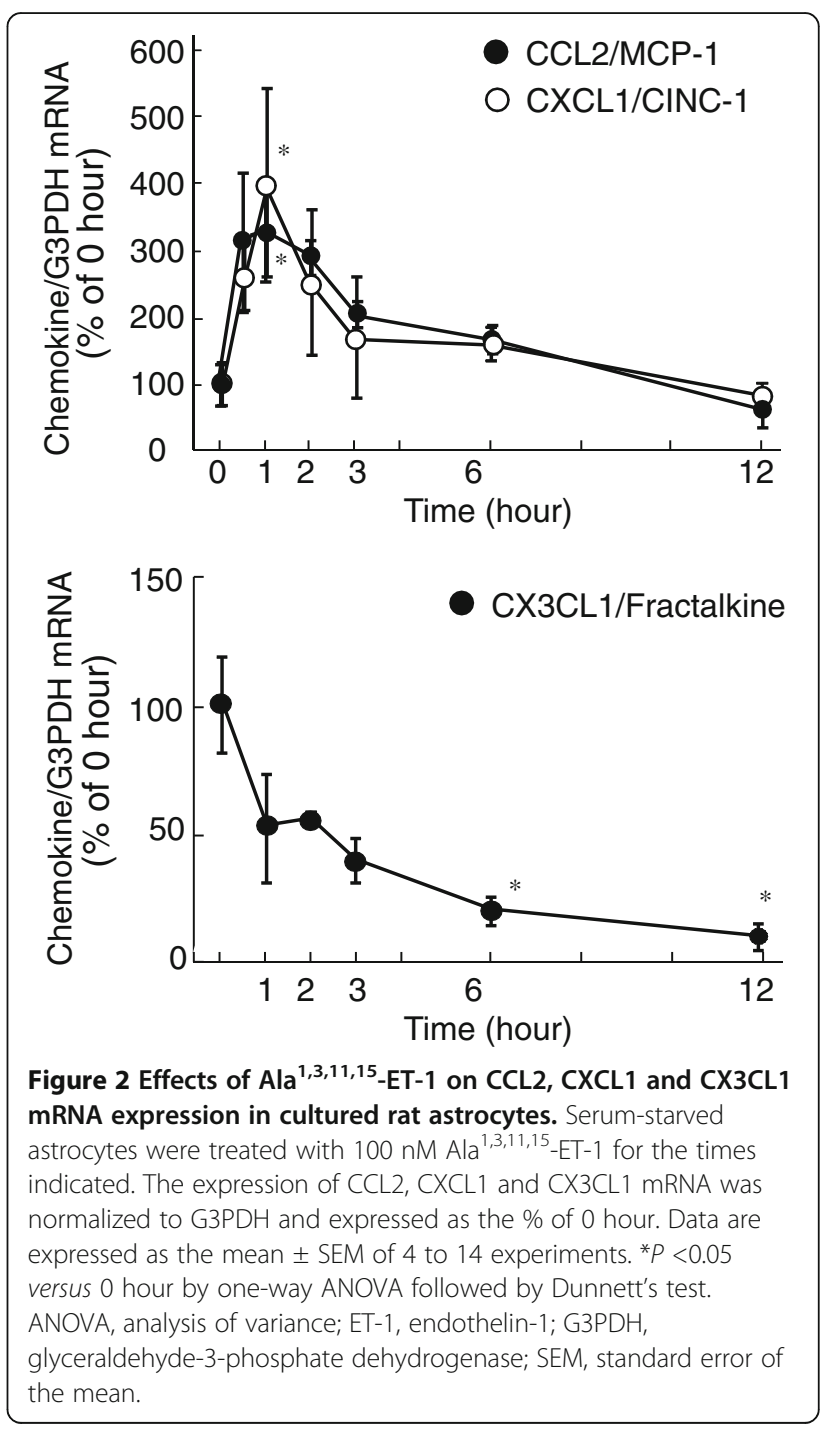


Figure 3 Effects of ET receptor antagonists on ET-induced changes in CCL2, CXCL1 and CX3CL1 mRNA levels. Serumstarved astrocytes were treated with $10 \mathrm{nM} \mathrm{ET-1}$ for one (CCL2 and

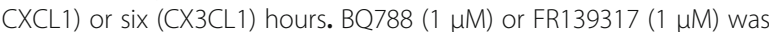
added to the medium 30 minutes before treatment with ET-1. The expression of CCL2, CXCL1 and CX3CL1 mRNA was normalized to G3PDH and expressed as the \% of no treatment cultures. Data are the mean \pm SEM of five to nine experiments. ${ }^{*} P<0.05$, ${ }^{*} P<0.01$ versus no ET-1, ${ }^{\#} P<0.05,{ }^{\# \#} P<0.01$ versus ET- 1 with no antagonist by one-way ANOVA followed by Fisher's PLSD test. ANOVA, analysis of variance; $\mathrm{ET}$, endothelin; G3PDH, glyceraldehyde-3-phosphate dehydrogenase; NS, not significant; PLSD, protected least significant difference; SEM, standard error of the mean.

FR139317 $(1 \mu \mathrm{M})$, an $\mathrm{ET}_{\mathrm{A}}$ antagonist, did not inhibit the effects of ET-1 on astrocytic CCL2, CXCL1 and CX3CL1 mRNA levels. The effects of ET-1 on chemokine release from cultured astrocytes were examined. Treatment with $100 \mathrm{nM}$ ET-1 for 1.5 to 3 hours increased the release of CCL2 and CXCL1 protein in the culture medium, while release of CX3CL1 protein into the culture medium decreased in the presence of ET-1 (Figure 4).

\section{Effects of signal transduction inhibitors on the ET-induced} alterations of chemokine production

The expression of the mRNAs of several chemokines is regulated by transcriptional mechanisms and alterations of mRNA stability. Involvement of transcriptional mechanisms in the ET-induced alterations of astrocytic chemokine production were examined by using actinomycin $\mathrm{D}$, a transcription inhibitor. Actinomycin D $(1 \mu \mathrm{g} / \mathrm{mL})$ gradually decreased basal expressions of CCL2 and CXCL1 mRNAs in the treatments up to 60 minutes, although the effects were not statistically significant (Figure $5 \mathrm{~A}$ and $\mathrm{B}$ ). In the presence of actinomycin D, ET-1 did not increase astrocytic CCL2 and CXCL1 mRNAs (Figure 5A and B). On the other hand, the ETinduced decrease in CX3CL1 expression was not affected by actinomycin D (Figure 5A and B). Cycloheximide $(10 \mu \mathrm{g} / \mathrm{mL})$, a protein synthesis inhibitor, had no effect on ET-induced CCL2 and CXCL1 expression, but prevented the decrease in CX3CL1 expression (Figure 5A).

$\mathrm{ET}_{\mathrm{B}}$ receptors belong to Gq-protein coupled receptors. Activation of astrocytic $\mathrm{ET}_{\mathrm{B}}$ receptors induces an increase in cytosolic $\mathrm{Ca}^{2+}$ and activation of protein kinase $\mathrm{C}$ (PKC) and mitogen-activated protein (MAP) kinases [25,33-35]. $\mathrm{Ca}^{2+}$ chelation (a combination of $0.5 \mathrm{mM}$ ethylene glycol tetraacetic acid (EGTA) and $30 \mu \mathrm{M} 1,2-$ bis(2-aminophenoxy)ethane N,N,N',N'-tetraacetic acid acetoxymethyl ester. (BAPTA/AM)) and PKC inhibition (staurosporine, $10 \mathrm{nM}$ ) did not affect ET-induced CCL2 and CXCL1 mRNA expression (Table 2). On the other hand, the decrease in CX3CL1 expression was inhibited by $\mathrm{Ca}^{2+}$ chelation and staurosporine. The inhibition by staurosporine was BAPTA/AM dose-dependent, where a 


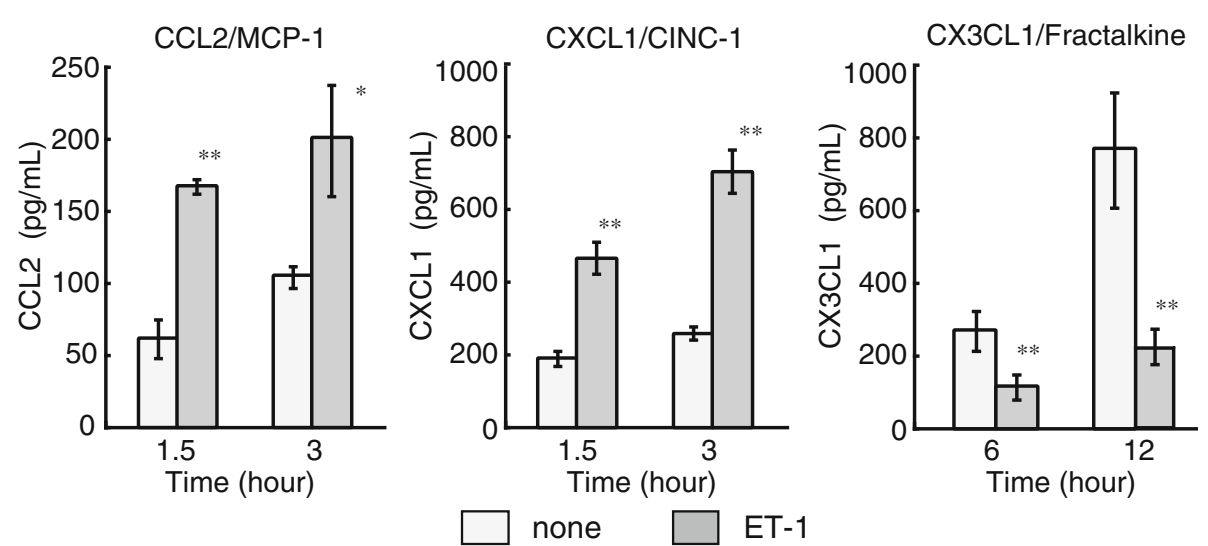

Figure 4 Effect of ET-1 on immunoreactive CCL2, CXCL1 and CX3CL1 released from cultured astrocytes. Astrocytes were cultured in serum-free MEM in the absence or presence of $100 \mathrm{nM}$ ET-1 for the times indicated. Concentrations of immunoreactive CCL2, CXCL1 and CX3CL1 in the culture medium were measured by ELISA. Results are the mean \pm SEM of six to eight experiments. ${ }^{*} P<0.05,{ }^{*} P<0.01$ versus no ET-1 by one-way ANOVA followed by Fisher's PLSD test. ANOVA, analysis of variance; ET, endothelin; MEM, minimal essential medium; PLSD, protected least significant difference; SEM, standard error of the mean.

significant effect was obtained at $10 \mathrm{nM}$ (Figure 6). SB203580 (a p38 inhibitor) and SP600125 (a JNK inhibitor) inhibited the effect of ET-1 on CCL2 and CXCL1 expression in a dose-dependent manner, but PD98059 (an ERK inhibitor, $50 \mu \mathrm{M}$ ) had no effect (Table 2 and Figure 6). The ET-induced decrease in CX3CL1 expression was not affected by these MAP kinase inhibitors (Table 2). Pyrrolidine dithiocarbamate (PDTC, $100 \mu \mathrm{M}$ ) and SN50 $(10 \mu \mathrm{M})$, which inhibits the transcriptional activities of nuclear factor-kappaB $(\mathrm{NF \kappa B})$, reduced ETinduced CCL2 and CXCL1 expressions, while these inhibitors did not alter the effects of ET-1 on CX3CL1 expression (Table 2 and Figure 6). Mithramycin (500 nM), an inhibitor of transcription factor SP1, diminished ETinduced CCL2 and CXCL1 expression, but had no effect on the decrease of CX3CL1 expression (Table 2 and Figure 6). At the highest concentrations used, these signal transduction inhibitors did not largely affect basal expressions of astrocytic CCL2, CXCL1 and CX3CL1 mRNAs [see Additional file 1].

\section{Discussion}

\section{ETs increase astrocytic CCL2 and CXCL1 production}

Various chemokines, including CCL2, CXCL1, CCL5, CXCL12 and CX3CL1, are constitutively or inducibly expressed in the adult brain. A comparison of these chemokine mRNA levels in cultured neurons, microglia and astrocytes (Table 1) revealed higher expression of CCL2 and CXCL1 in astrocytes. The higher expression of CCL2 and CXCL1 in cultured astrocytes is in agreement with the observation that astrocytes are the main source of these chemokines [3]. We previously showed that intracerebroventricular administration of an $\mathrm{ET}_{\mathrm{B}}$ agonist increased CCL2 and CXCL1 production in rat cerebral astrocytes [28]. In this study, treatment with ETs stimulated the production and release of CCL2 and CXCL1 in cultured astrocytes (Figures 1 and 4). The effect of ET receptor agonist and antagonists showed that the actions of ET-1 were mediated by $\mathrm{ET}_{\mathrm{B}}$ receptors (Figures 2 and 3). From these findings, activation of astrocytic $\mathrm{ET}_{\mathrm{B}}$ receptors is thought to stimulate CCL2 and CXCL1 production directly. Increased production of astrocytic CCL2 and CXCL1 was observed in nerve tissue damaged by brain ischemia and neurodegenerative diseases $[4,6,36,37]$. Brain ETs have been shown to be increased in several brain pathologies and regulate several pathophysiological responses of astrocytes, including the production of extracellular signaling molecules, through $\mathrm{ET}_{\mathrm{B}}$ receptors [27]. Thus, the ET-induced chemokine production in cultured astrocytes suggests that ETs are one of the factors to stimulate CCL2 and CXCL1 production at the damaged nerve area.

\section{ETs decrease astrocytic CX3CL1 production}

Differing from CCL2 and CXCL1, production of astrocytic CX3CL1 decreased following treatment with ETs (Figures 1 and 4), which was also mediated by $\mathrm{ET}_{\mathrm{B}}$ receptors (Figures 2 and 3). CX3CL1 is relatively abundant in the brain, where sub-populations of neurons constitutively express the protein [1]. We found that cultured astrocytes had a comparably high level of CX3CL1 when compared to cerebral neurons (Table 1). As for the regulation of astrocytic CX3CL1, pro-inflammatory cytokines, such as tumor necrosis factor alpha (TNF $\alpha$ ) and IFN- $\gamma$, stimulate its production in cultured astrocytes [38]. On the other hand, a negative-regulatory mechanism of constitutive CX3CL1 production was suggested by the finding that basal CX3CL1 production in human astrocytomas was reduced by tumor growth factor beta (TGF $\beta$ ) [18]. The effects of ETs on CX3CL1 production 

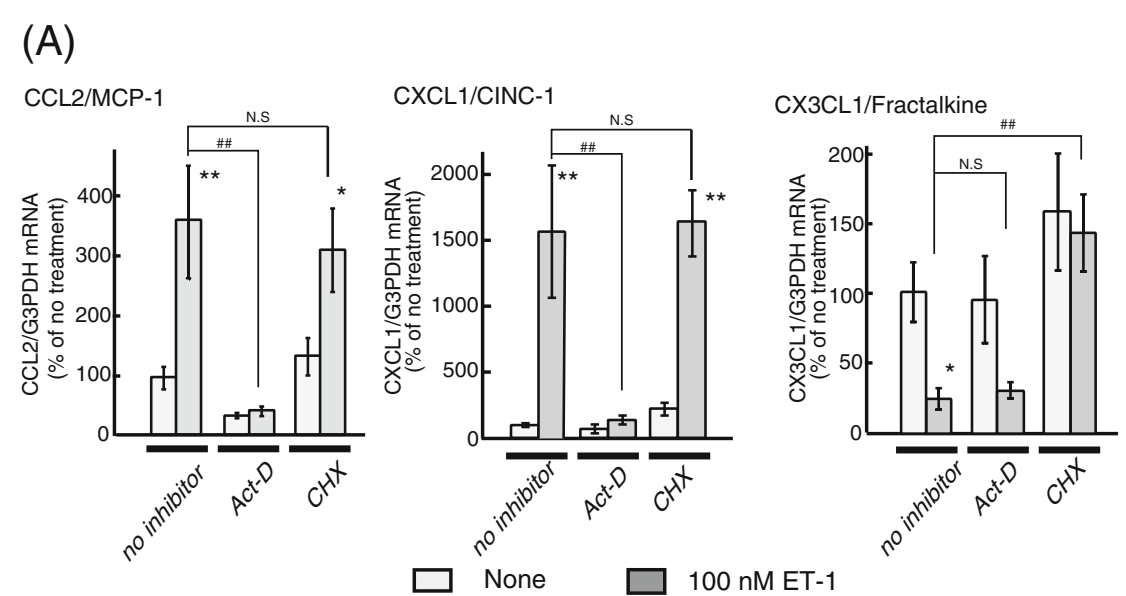

(B)
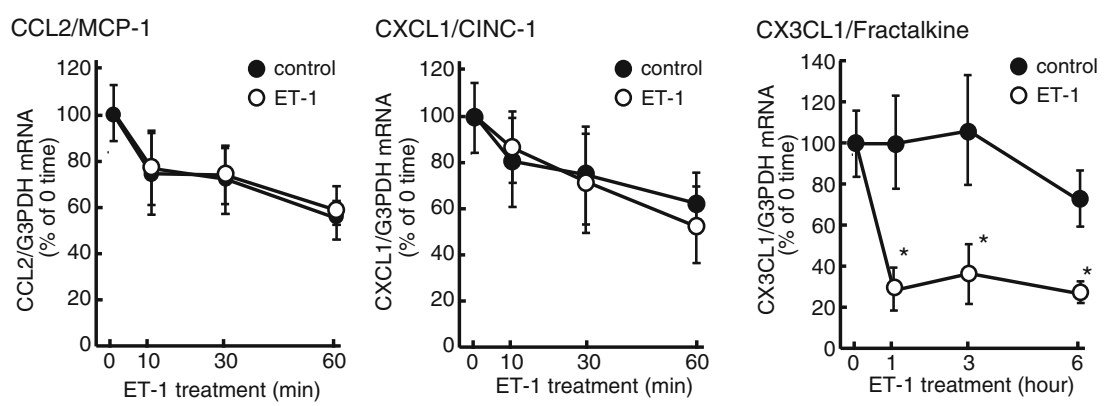

Figure 5 Effects of actinomycin D and cycloheximide on ET-induced changes in CCL2, CXCL1 and CX3CL1 mRNA levels. (A) Serumstarved astrocytes were treated with $100 \mathrm{nM} \mathrm{ET-1}$ for one (CCL2 and CXCL1) or six (CX3CL1) hours. Actinomycin D (Act-D, $1 \mu \mathrm{g} / \mathrm{mL})$ or cycloheximide $(\mathrm{CHX}, 10 \mu \mathrm{g} / \mathrm{mL})$ was added to the medium 30 minutes before treatment with ET-1. The expression of CCL2, CXCL1 and CX3CL1 mRNA was normalized to G3PDH and expressed as the \% of no treatment cultures. Data are the mean \pm SEM of 8 to 15 experiments. ${ }^{*} P<0.05$, ${ }^{* *} P<0.01$ versus no $E T-1,{ }^{\# \# P}<0.01$ versus no inhibitor by one-way ANOVA followed by Fisher's PLSD test. NS, not significant. (B) Effects of ET-1 on CCL2, CXCL1 and CX3CL1 mRNA expressions in the presence of actinomycin D. Cultured astrocytes were treated with (open circle) or without

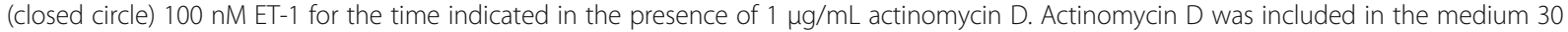
minutes before treatment with ET-1. Data are the mean \pm SEM of six experiments. ${ }^{*} P<0.05$ versus control by one-way ANOVA followed by Fisher's PLSD test. ANOVA, analysis of variance; ET-1, endothelin-1; G3PDH, glyceraldehyde-3-phosphate dehydrogenase; PLSD, protected least significant difference; SEM, standard error of the mean.

indicate an involvement of $\mathrm{ET}_{\mathrm{B}}$ receptors in the negative-regulation of astrocytic CX3CL1 production. Recently, Donnelly et al. [39] showed that expression of CX3CL1 decreased after spinal cord injury in mice, although its cellular sources were not identified. Thus, the negative regulation of astrocytic CX3CL1 by ETs may reflect the reduced CX3CL1 expression in damaged nerve tissues.

\section{Signal transduction mechanisms mediating the ET- induced chemokine production}

Activation of astrocytic $\mathrm{ET}_{\mathrm{B}}$ receptors stimulates several intracellular signal pathways, including PKC, intracellular $\mathrm{Ca}^{2+}$, and MAP kinases. The effects of ET-1 on astrocytic chemokine production were significant at 10 to $100 \mathrm{nM}$ (Figure 1B), which concentrations of ET-1 activated signal mechanisms mediated by $\mathrm{PKC}, \mathrm{Ca}^{2+}$ and MAP kinases [25,33-35]. The effects of signal transduction inhibitors (Table 2 and Figure 5) showed that different mechanisms mediate $\mathrm{ET}_{\mathrm{B}}$ receptor signals to regulate astrocytic chemokine expression. In addition to the regulation of gene transcription, expression levels of CCL2, CXCL1 and CX3CL1 mRNA can be regulated by alteration of their stabilities [40-43]. The effect of ET-1 on CCL2 and CXCL1 mRNA expression was inhibited by actinomycin D (Figure 5A). Further examination showed that treatments with ET-1 did not affect the degradation rates of astrocytic CCL2 and CXCL1 mRNAs (Figure 5B). These results suggest that stimulation of transcription, rather than increases in mRNA stability, underlie ET-induced astrocytic CCL2 and CXCL1 expression. Both rat CCL2 and CXCL1 genes have recognition sequences for $\mathrm{NFkB}$ and SP1 on the 5 '-promotor regions. Through these recognition sites, transcription of CCL2 and CXCL1 are cooperatively stimulated by NFkB and SP1 [44-47]. Agreeing with these findings, the inhibition 
Table 2 Effect of signal transduction inhibitors on ET-induced expression of CCL2, CXCL1 and CX3CL1 mRNA

\begin{tabular}{|c|c|c|c|}
\hline & \multicolumn{3}{|c|}{ Ratio of chemokine to G3PDH mRNA copy number } \\
\hline & \multicolumn{3}{|c|}{ (\% of no treatment) } \\
\hline & CCL2/MCP-1 & CXCL1/CINC-1 & CX3CL1/fractalkine \\
\hline no treatment & $100.0 \pm 31.4(20)$ & $100.0 \pm 22.0(20)$ & $100.0 \pm 17.5(24)$ \\
\hline 100 nM ET-1 & $313.8 \pm 65.1(20)^{\mathrm{a}}$ & $404.7 \pm 63.9(20)^{a}$ & $37.5 \pm 8.5(23)^{a}$ \\
\hline + $30 \mu \mathrm{M}$ BAPTA/0.5 mM EGTA & $307.4 \pm 89.0(7)$ & $342.7 \pm 65.0(7)$ & $122.8 \pm 25.2(9)^{\mathrm{b}}$ \\
\hline$+10 \mathrm{nM}$ staurosporine & $444.8 \pm 122.3(6)$ & $385.4 \pm 79.0(6)$ & $108.6 \pm 25.6(4)^{b}$ \\
\hline$+100 \mu \mathrm{M}$ PDTC & $129.2 \pm 16.5(12)^{b}$ & $140.2 \pm 20.7(12)^{b}$ & $42.5 \pm 8.8(18)$ \\
\hline$+10 \mu \mathrm{M}$ SN50 & $188.7 \pm 64.3(8)^{b}$ & $136.1 \pm 22.6(8)^{b}$ & $54.6 \pm 23.9(11)$ \\
\hline + 500 nM mithramycin & $37.8 \pm 9.2(8)^{c}$ & $49.8 \pm 24.1(8)^{c}$ & $36.3 \pm 11.7(10)$ \\
\hline + 50 нM PD98059 & $277.4 \pm 90.7(12)$ & $360.2 \pm 103.2(12)$ & $49.6 \pm 7.2(10)$ \\
\hline$+20 \mu \mathrm{M}$ SB203580 & $118.3 \pm 36.9(13)^{c}$ & $229.1 \pm 73.6(13)^{b}$ & $37.1 \pm 6.3(20)$ \\
\hline$+1 \mu \mathrm{M}$ SP600125 & $110.2 \pm 23.6(8)^{b}$ & $188.5 \pm 22.5(8)^{\mathrm{b}}$ & $47.1 \pm 22.0(10)$ \\
\hline
\end{tabular}

${ }^{\mathrm{a}} P<0.01$ versus no treatment, ${ }^{\mathrm{b}} P<0.05,{ }^{\mathrm{c}} \mathrm{P}<0.01$, versus $100 \mathrm{nM} \mathrm{ET-1}$ by one-way ANOVA followed by Fisher's PLSD test. Astrocytes were treated with $100 \mathrm{nM}$ ET-1 in the presence of the signal transduction inhibitors indicated. Total RNA was extracted at one hour (for CCL2 and CXCL1) or six hours (for CX3CL1) after the addition of ET-1. The inhibitors were included in the serum-free medium for 30 minutes before the addition of ET-1. The copy numbers of CCL2, CXCL1 and CX3CL1 mRNA was normalized to G3PDH. Results are the mean \pm SEM and the numbers of experiments are indicated in parentheses. ANOVA, analysis of variance; BAPTA/AM, 1,2-bis(2-aminophenoxy)ethane N,N,N',N'-tetraacetic acid acetoxymethyl ester; ET, endothelin; G3PDH, glyceraldehyde-3-phosphate dehydrogenase; PDCT, pyrrolidine dithiocarbamate; PLSD, protected least significant difference; SEM, standard error of the mean.

of astrocytic CCL2 and CXCL1 expression by PDTC, SN50 and mithramycin suggests the involvement of both $\mathrm{NF}_{\kappa} \mathrm{B}$ and SP1 in the effect of ET-1. MAP kinases, that is, ERK, JNK and p38, regulate the transcription activities of $\mathrm{NFKB}$ and SP1 in signal transduction pathways under several receptors. In astrocytes, activation of JNK and p38 was reported to stimulate NFkB $[48,49]$. We also found that ET-induced activation (phosphorylation) of SP1 was reduced by SP600125 in cultured astrocytes [see Additional file 2]. Thus, the inhibition of ET-induced CCL2 and CXCL1 expression by SP600125 and SB203580 may indicate that JNK and p38 mediate ET receptor signals to $\mathrm{NFKB}$ and SP1.

Differing from the effects on CCL2 and CXCL1 expression, the ET-induced decrease in CX3CL1 mRNA was inhibited by cycloheximide (Figure 5A). This result indicates a requirement of protein de novo synthesis for the effect of ETs on fractalkine expression. Moreover, $\mathrm{Ca}^{2+}$ chelation and PKC inhibition, but not MAP kinase inhibition, prevented the effects of ET-1. Rat CX3CL1 mRNA has AU-rich elements in the 3 ' regions, where many regulatory proteins affecting mRNA stability bind [42]. As is reported in the regulatory mechanisms of some inflammatory factors [50], ET may stimulate the induction of regulatory proteins that destabilize CX3CL1 mRNA through $\mathrm{Ca}^{2+}$ - and PKC-dependent signals.

\section{Pathophysiological significance of the ET-induced changes in astrocytic chemokine production}

In nerve tissues damaged by brain insults and neurodegenerative diseases, astrocytes undergo a phenotypic change to reactive astrocytes and alter their ability to produce various chemokines [7]. By altering the production of astrocyte-derived chemokines, the pathophysiological response of the damaged brain is modulated. In brain pathologies, brain ETs increase in damaged tissues, which activate astrocytic $\mathrm{ET}_{\mathrm{B}}$ receptors and induce reactive astrocytosis [25,26]. Accompanied with the conversion to reactive astrocytes, ETs modulate the production of various extracellular signaling molecules [27]. A major finding of the present study is that ETs had different actions on astrocytic chemokine production: ETs increased CCL2 and CXCL1, but decreased CX3CL1 production (Figures 1 and 4). The reciprocal regulation of astrocyte-derived chemokines would result in the possible modulation of chemokine-induced pathological brain responses by ETs. In the brain, receptors for CCL2, CXCL1 and CX3CL1 are expressed in vascular endothelial cells, neurons and microglia [1]. CCL2, CXCL1 and CX3CL1 all stimulate the proliferation and migration of vascular endothelial cells [51-53], which indicates that these chemokines have similar actions on neovascularization after brain injuries. The function of these chemokines on neuronal cells is controversial. While CX3CL1 showed a neuroprotective effect $[9,11]$, CCL2 and CXCL1 were reported to be detrimental [8] or protective $[10,12]$ on neuronal cells. Thus, the possible significance of ET-induced astrocytic chemokine production would be difficult to discuss in view of the function of neurons and vascular endothelial cells.

On the other hand, the action of CX3CL1 opposes that of CCL2 and CXCL1 in the regulation of microglial function. CCL2 and CXCL1 caused the activation of cultured microglia and stimulated the production of 

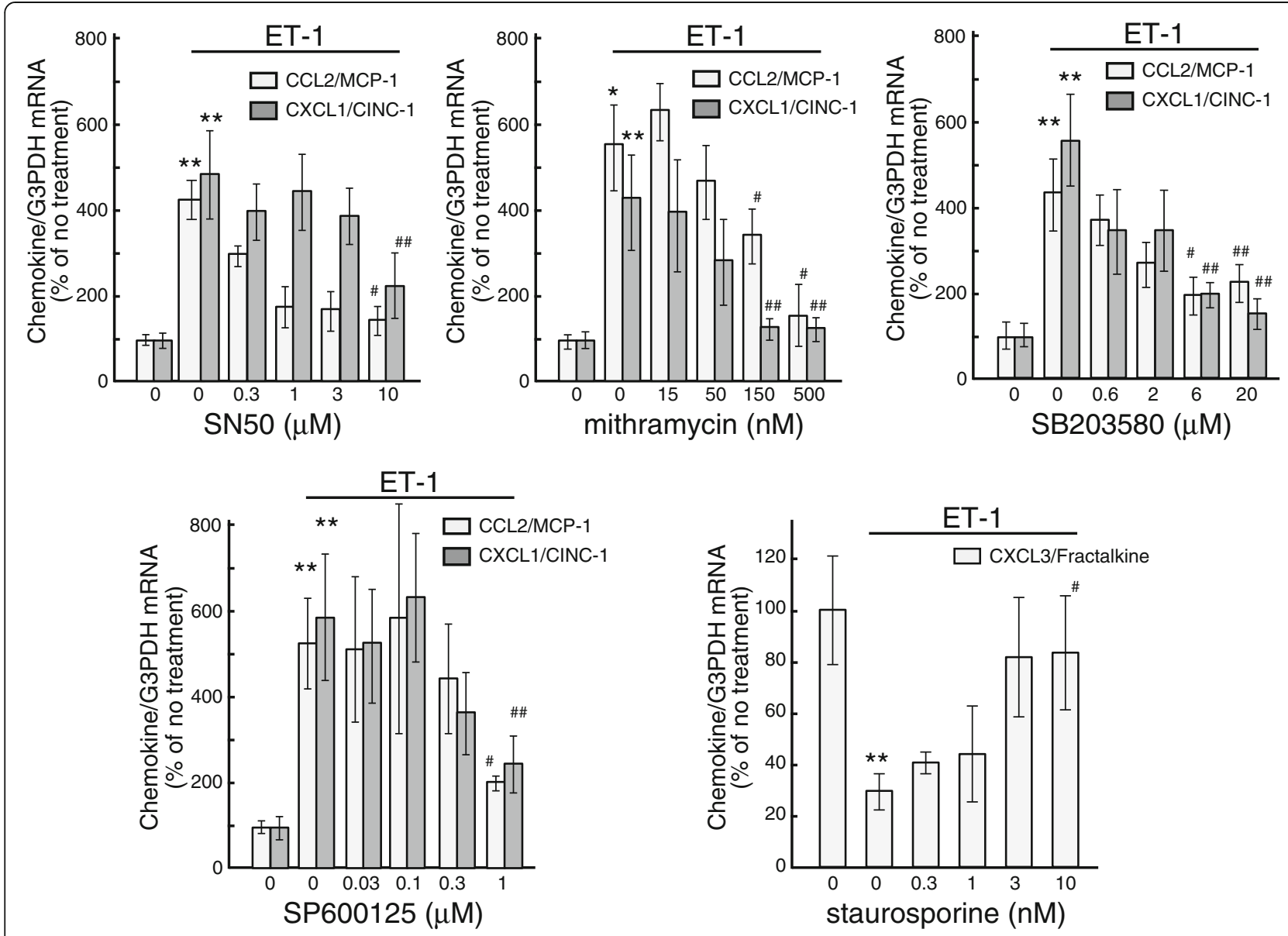

Figure 6 Dose-dependent inhibition of ET-induced changes in CCL2, CXCL1 and CX3CL1 mRNA levels by signal transduction inhibitors. Serum-starved astrocytes were treated with 100 nM ET-1 for one (CCL2 and CXCL1) or six (CX3CL1) hours. Different concentrations of signal transduction inhibitors (SN50, mithramycin, SB203580, SP600125 and staurosporine) were included in the medium 30 minutes before treatment with ET-1. The expression of CCL2, CXCL1 and CX3CL1 mRNA was normalized to G3PDH and expressed as the \% of no treatment cultures. Data are the mean \pm SEM of 6 to 12 experiments. ${ }^{*} P<0.05$, ${ }^{*} P<0.01$ versus no treatment, ${ }^{\#} P<0.05,{ }^{\# \#} P<0.01$ versus ET- 1 with no inhibitor by one-way ANOVA followed by Fisher's PLSD test. ANOVA, analysis of variance; ET, endothelin; G3PDH, glyceraldehyde-3-phosphate dehydrogenase; PLSD, protected least significant difference; SEM, standard error of the mean.

proinflammatory molecules [19,54]. Inhibition of CCL2 signals attenuated microglial activation and proinflammatory cytokine production in animal models of brain injury $[19,55]$. Pro-inflammatory cytokine production and migration in cultured microglia were stimulated by CXCL8/IL-8, a human homologue of rat CXCL1 $[14,15]$. In contrast, CX3CL1 attenuated microglial activation and proinflammatory cytokine production in vitro and in vivo [16,17]. Mice lacking CX3CL1 receptors showed enhanced activation of microglia in response to lipopolysaccharide [13], indicating a repressive role of CX3CL1 in microglial function. Considering the different actions among CCL2, CXCL1 and CX3CL1 on microglia, the reciprocal regulation of astrocytic chemokine production by ETs may have a pathophysiological significance in the induction of activated microglia. Induction of activated microglia promotes the neuroinflammatory response and results in the aggravation of neuronal degradation. Thus, the increase in ETs after brain insults and neurodegenerative diseases may show a detrimental action on the damaged brain through microglial activation induced by altered astrocytic chemokine production.

\section{Conclusions}

In this study, activation of $\mathrm{ET}_{\mathrm{B}}$ receptors altered the production of CCL2, CXCL1 and CX3CL1 in cultured astrocytes. Because astrocytes are a main source of brain chemokines in neurological disorders, alterations of astrocytic chemokine production affect several responses of the damaged brain. Thus, ET-induced alterations of astrocytic chemokine production indicate a pathophysiological significance of astrocytic $\mathrm{ET}_{\mathrm{B}}$ receptors. 


\section{Additional files}

\section{Additional file 1: Effects of signal transduction inhibitors on CCL2, CXCL1 and CX3CL1 mRNA levels in cultured astrocytes. \\ Additional file 2: Effects of MAPK inhibitors on the ET-induced phosphorylation of SP1.}

\section{Abbreviations}

ANOVA: analysis of variance; BAPTA/AM: 1,2-bis(2-aminophenoxy)ethane $\mathrm{N}, \mathrm{N}$, N',N'-tetraacetic acid acetoxymethyl ester; CINC-1: cytokine-induced neutrophil chemoattractant-1; DMSO: dimethyl sulfoxide; EGTA: ethylene glycol tetraacetic acid; ELISA: enzyme-linked immunosorbent assay; ET: endothelin; G3PDH: glyceraldehyde-3-phosphate dehydrogenase; GFAP: glial fibrillary acidic protein; IFN: interferon; IL: interleukin; MAP: mitogen-activated protein; MCP-1: monocyte chemoattractant protein1; MEM: minimal essential medium; NFKB: nuclear factor-KappaB; PDTC: pyrrolidine dithiocarbamate; PKC: protein kinase C; PLSD: protected least significant difference; PCR: polymerase chain reaction; RT: reverse transcriptase; SDF-1: stromal cell-derived factor-1; SEM: standard error of the mean; TGF: tumor growth factor; TNF: tumor necrosis factor..

\section{Competing interests}

The authors declare they have no competing interests.

\section{Authors' contributions}

YK and MS participated in the design of this study and the preparation of the manuscript. YK, MK, TS, MK and RK preformed the research work. All authors read and approved the final manuscript.

\section{Acknowledgments}

This work was supported by a Grant-in-Aid for Scientific Research (C) from the JPSP (21590108).

Received: 20 November 2012 Accepted: 2 April 2013

Published: 30 April 2013

\section{References}

1. Cartier L, Hartley O, Dubois-Dauphin M, Krause KH: Chemokine receptors in the central nervous system: role in brain inflammation and neurodegenerative diseases. Brain Res Brain Res Rev 2005, 48:16-42.

2. de Haas AH, van Weering HR, de Jong EK, Boddeke HW, Biber KP: Neuronal chemokines: versatile messengers in central nervous system cell interaction. Mol Neurobiol 2007, 36:137-151.

3. Jaerve A, Müller HW: Chemokines in CNS injury and repair. Cell Tissue Res 2012, 349:229-248.

4. Gourmala NG, Buttini M, Limonta S, Sauter A, Boddeke HW: Differential and time-dependent expression of monocyte chemoattractant protein-1 mRNA by astrocytes and macrophages in rat brain: effects of ischemia and peripheral lipopolysaccharide administration. J Neuroimmunol 1997, 74:35-44.

5. Ishizuka K, Kimura T, Igata-yi R, Katsuragi S, Takamatsu J, Miyakawa T: Identification of monocyte chemoattractant protein-1 in senile plaques and reactive microglia of Alzheimer's disease. Psychiatry Clin Neurosci 1997, 51:135-138.

6. Liu T, Young PR, McDonnell PC, White RF, Barone FC, Feuerstein GZ: Cytokine-induced neutrophil chemoattractant mRNA expressed in cerebral ischemia. Neurosci Lett 1993, 164:125-128.

7. Sofroniew MV: Molecular dissection of reactive astrogliosis and glial scar formation. Trends Neurosci 2009, 32:638-647.

8. Kalehua AN, Nagel JE, Whelchel LM, Gides JJ, Pyle RS, Smith RJ, Kusiak JW, Taub DD: Monocyte chemoattractant protein-1 and macrophage inflammatory protein-2 are involved in both excitotoxin-induced neurodegeneration and regeneration. Exp Cell Res 2004, 297:197-211.

9. Krathwohl MD, Kaiser $\mathrm{JL}$ : Chemokines promote quiescence and survival of human neural progenitor cells. Stem Cells 2004, 22:109-118.

10. Madrigal JL, Leza JC, Polak P, Kalinin S, Feinstein DL: Astrocyte-derived MCP-1 mediates neuroprotective effects of noradrenaline. J Neurosci 2009, 29:263-267.
11. Meucci $O$, Fatatis A, Simen AA, Miller RJ: Expression of CX3CR1 chemokine receptors on neurons and their role in neuronal survival. Proc Natl Acad Sci U S A 2000, 97:8075-8080

12. Watson K, Fan GH: Macrophage inflammatory protein 2 inhibits betaamyloid peptide (1-42)-mediated hippocampal neuronal apoptosis through activation of mitogen-activated protein kinase and phosphatidylinositol 3-kinase signaling pathways. Mol Pharmacol 2005, 67:757-765.

13. Corona AW, Huang Y, O'Connor JC, Dantzer R, Kelley KW, Popovich PG Godbout JP: Fractalkine receptor (CX3CR1) deficiency sensitizes mice to the behavioral changes induced by lipopolysaccharide. J Neuroinflammation 2010, 7:93.

14. Cross AK, Woodroofe MN: Chemokines induce migration and changes in actin polymerization in adult rat brain microglia and a human fetal microglial cell line in vitro. J Neurosci Res 1999, 55:17-23.

15. Franciosi S, Choi HB, Kim SU, McLarnon JG: IL-8 enhancement of amyloidbeta (Abeta 1-42)-induced expression and production of proinflammatory cytokines and COX-2 in cultured human microglia. J Neuroimmunol 2005, 159:66-74.

16. Lyons A, Lynch AM, Downer EJ, Hanley R, O'Sullivan JB, Smith A, Lynch MA: Fractalkine-induced activation of the phosphatidylinositol-3 kinase pathway attentuates microglial activation in vivo and in vitro. J Neurochem 2009, 110:1547-1556.

17. Pabon MM, Bachstetter AD, Hudson CE, Gemma C, Bickford PC: CX3CL1 reduces neurotoxicity and microglial activation in a rat model of Parkinson's disease. J Neuroinflammation 2011, 8:9.

18. Sciumè G, Soriani A, Piccoli M, Frati L, Santoni A, Bernardini G: CX3CR1/ CX3CL1 axis negatively controls glioma cell invasion and is modulated by transforming growth factor- $\beta 1$. Neuro Oncol 2010, 12:701-710.

19. Yang G, Meng $Y$, Li W, Yong $Y$, Fan Z, Ding H, Wei $Y$, Luo J, Ke ZJ: Neuronal MCP-1 mediates microglia recruitment and neurodegeneration induced by the mild impairment of oxidative metabolism. Brain Pathol 2011, 21:279-297

20. Nie XJ, Olsson Y: Endothelin peptides in brain diseases. Rev Neurosci 1996 7:177-186.

21. Ostrow LW, Sachs F: Mechanosensation and endothelin in astrocyteshypothetical roles in CNS pathophysiology. Brain Res Brain Res Rev 2005, 48:488-508

22. Prasanna G, Krishnamoorthy R, Yorio T: Endothelin, astrocytes and glaucoma. Exp Eye Res 2011, 93:170-177.

23. Rogers SD, Peters CM, Pomonis JD, Hagiwara H, Ghilardi JR, Mantyh PW: Endothelin $B$ receptors are expressed by astrocytes and regulate astrocyte hypertrophy in the normal and injured CNS. Glia 2003, 41:180-190.

24. Wilhelmsson U, Li L, Pekna M, Berthold CH, Blom S, Eliasson C, Renner O, Bushong E, Ellisman M, Morgan TE, Pekny M: Absence of glial fibrillary acidic protein and vimentin prevents hypertrophy of astrocytic processes and improves post-traumatic regeneration. J Neurosci 2004, 24:5016-5021.

25. Gadea A, Schinelli S, Gallo V: Endothelin-1 regulates astrocyte proliferation and reactive gliosis via a JNK/C-Jun signaling pathway. J Neurosci 2008, 28:2394-2408.

26. Koyama $Y$, Takemura M, Fujiki $K$, Ishikawa $N$, Shigenaga $Y$, Baba A BQ788, an endothelin $\mathrm{ET}_{\mathrm{B}}$ receptor antagonist, attenuates stab wound injury-induced reactive astrocytes in rat brain. Glia 1999, 26:268-271

27. Koyama Y, Michinaga S: Regulations of astrocytic functions by endothelins: roles in the pathophysiological responses of damaged brains. J Pharmacol Sci 2012, 118:401-407

28. Koyama Y, Baba A, Matsuda T: Production of monocyte chemoattractant protein-1 and cytokine-induced neutrophil chemoattractant- 1 in rat brain is stimulated by intracerebroventricular administration of an endothelin $\mathrm{ET}_{\mathrm{B}}$ receptor agonist. Neuroreport 2007, 18:1275-1279.

29. Koyama Y, Maebara Y, Hayashi M, Nagae R, Tokuyama S, Michinaga S: Endothelins reciprocally regulate VEGF-A and angiopoietin-1 production in cultured rat astrocytes: Implications on astrocytic proliferation. Glia 2012, 60:1954-1963.

30. Miyagishi R, Kikuchi S, Takayama C, Inoue $Y$, Tashiro K: Identification of cell types producing RANTES, MIP-1 $\alpha$ and MIP- $1 \beta$ in rat experimental autoimmune encephalomyelitis by in situ hybridization. $J$ Neuroimmunol 1997, 77:17-26. 
31. Tarozzo G, Campanella M, Ghiani M, Bulfone A, Beltramo M: Expression of fractalkine and its receptor, CX3CR1, in response to ischaemiareperfusion brain injury in the rat. Eur J Neurosci 2002, 15:1663-1668.

32. Tham TN, Lazarini F, Franceschini IA, Lachapelle F, Amara A, Dubois-Dalcq M: Developmental pattern of expression of the alpha chemokine stromal cell-derived factor 1 in the rat central nervous system. Eur J Neurosci 2001, 13:845-856.

33. Schinelli S, Zanassi P, Paolillo M, Wang H, Feliciello A, Gallo V: Stimulation of endothelin $B$ receptors in astrocytes induces CAMP response elementbinding protein phosphorylation and c-fos expression via multiple mitogen-activated protein kinase signaling pathways. J Neurosci 2001, 21:8842-8853.

34. Stanimirovic DB, Ball R, Mealing G, Morley P, Durkin JP: The role of intracellular calcium and protein kinase $C$ in endothelin-stimulated proliferation of rat type I astrocytes. Glia 1995, 15:119-130.

35. Supattapone S, Simpson AW, Ashley CC: Free calcium rise and mitogenesis in glial cells caused by endothelin. Biochem Biophys Res Commun 1989, 165:1115-1122.

36. Omari KM, John G, Lango R, Raine CS: Role for CXCR2 and CXCL1 on glia in multiple sclerosis. Glia 2006, 53:24-31.

37. Van Der Voorn $P$, Tekstra J, Beelen RH, Tensen CP, Van Der Valk P, De Groot $\mathrm{CJ}$ : Expression of MCP-1 by reactive astrocytes in demyelinating multiple sclerosis lesions. Am J Pathol 1999, 154:45-51.

38. Yoshida H, Imaizumi T, Fujimoto K, Matsuo N, Kimura K, Cui X, Matsumiya T, Tanji K, Shibata T, Tamo W, Kumagai M, Satoh K: Synergistic stimulation, by tumor necrosis factor-alpha and interferon-gamma, of fractalkine expression in human astrocytes. Neurosci Lett 2001, 303:132-136.

39. Donnelly DJ, Longbrake EE, Shawler TM, Kigerl KA, Lai W, Tovar CA, Ransohoff RM, Popovich PG: Deficient CX3CR1 signaling promotes recovery after mouse spinal cord injury by limiting the recruitment and activation of Ly6Clo/iNOS+ macrophages. J Neurosci 2011, 31:9910-9922.

40. Datta S, Biswas R, Novotny M, Pavicic PG Jr, Herjan T, Mandal P, Hamilton TA: Tristetraprolin regulates CXCL1 (KC) mRNA stability. J Immunol 2008, 180:2545-2552.

41. Fan J, Ishmael FT, Fang X, Myers A, Cheadle C, Huang SK, Atasoy U, Gorospe M, Stellato C: Chemokine transcripts as targets of the RNA-binding protein HuR in human airway epithelium. J Immunol 2011, 186:24822494

42. Matsumiya T, Ota K, Imaizumi T, Yoshida H, Kimura H, Satoh K: Characterization of synergistic induction of CX3CL1/fractalkine by TNFalpha and IFN-gamma in vascular endothelial cells: an essential role for TNF-alpha in post-transcriptional regulation of CX3CL1. J Immuno/ 2010 184:4205-4214.

43. Sauer I, Schaljo B, Vogl C, Gattermeier I, Kolbe T, Müller M, Blackshear PJ, Kovarik P: Interferons limit inflammatory responses by induction of tristetraprolin. Blood 2006, 107:4790-4797.

44. Lim SP, Garzino-Demo A: The human immunodeficiency virus type 1 Tat protein up-regulates the promoter activity of the beta-chemokine monocyte chemoattractant protein 1 in the human astrocytoma cell line U-87 MG: role of SP-1, AP-1, and NF-kappaB consensus sites. J Virol 2000, 74:1632-1640.

45. Ping D, Boekhoudt G, Zhang F, Morris A, Philipsen S, Warren ST, Boss JM: Sp1 binding is critical for promoter assembly and activation of the MCP1 gene by tumor necrosis factor. J Biol Chem 2000, 275:1708-1714

46. Thompson $\mathrm{WL}$, Van Eldik $\mathrm{L}$ : Inflammatory cytokines stimulate the chemokines CCL2/MCP-1 and CCL7/MCP-3 through NFkB and MAPK dependent pathways in rat astrocytes. Brain Res 2009, 1287:47-57.

47. Wood LD, Farmer AA, Richmond A: HMGI(Y) and Sp1 in addition to NFkappa $B$ regulate transcription of the MGSA/GRO alpha gene. Nucleic Acids Res 1995, 23:4210-4219.

48. Gorina R, Font-Nieves M, Márquez-Kisinousky L, Santalucia T, Planas AM: Astrocyte TLR4 activation induces a proinflammatory environment through the interplay between MyD88-dependent NFKB signaling, MAPK, and Jak1/Stat1 pathways. Glia 2011, 59:242-255.

49. Saha RN, Jana M, Pahan K: MAPK p38 regulates transcriptional activity of NF-kappaB in primary human astrocytes via acetylation of p65. $J$ Immunol 2007, 179:7101-7109.

50. Leppänen $\mathrm{T}$, Jalonen U, Korhonen R, Tuominen RK, Moilanen E: Inhibition of protein kinase Cdelta reduces tristetraprolin expression by destabilizing its mRNA in activated macrophages. Eur J Pharmacol 2010, 628:220-225.
51. Belperio JA, Keane MP, Arenberg DA, Addison CL, Ehlert JE, Burdick MD, Strieter RM: CXC chemokines in angiogenesis. J Leukocyte Biol. 2000, 68:1-8.

52. Hong $\mathrm{KH}$, Ryu J, Han $\mathrm{KH}$ : Monocyte chemoattractant protein-1-induced angiogenesis is mediated by vascular endothelial growth factor-A. Blood 2005, 105:1405-1407.

53. Volin MV, Woods JM, Amin MA, Connors MA, Harlow LA, Koch AE: Fractalkine: a novel angiogenic chemokine in rheumatoid arthritis. Am J Pathol 2001, 159:1521-1530.

54. Hinojosa AE, Garcia-Bueno B, Leza JC, Madrigal JL: CCL2/MCP-1 modulation of microglial activation and proliferation. J Neuroinflammation 2011, 8:77.

55. Semple BD, Bye N, Rancan M, Ziebell JM, Morganti-Kossmann MC: Role of CCL2 (MCP-1) in traumatic brain injury (TBI): evidence from severe TBI patients and CCL2-/- mice. J Cereb Blood Flow Metab 2010, 30:769-782.

doi:10.1186/1742-2094-10-51

Cite this article as: Koyama et al:: Different actions of endothelin-1 on chemokine production in rat cultured astrocytes: reduction of CX3CL1/ fractalkine and an increase in CCL2/MCP-1 and CXCL1/CINC-1. Journal of Neuroinflammation 2013 10:51.

\section{Submit your next manuscript to BioMed Central and take full advantage of:}

- Convenient online submission

- Thorough peer review

- No space constraints or color figure charges

- Immediate publication on acceptance

- Inclusion in PubMed, CAS, Scopus and Google Scholar

- Research which is freely available for redistribution

Submit your manuscript at www.biomedcentral.com/submit
C) Biomed Central 